\title{
OTONOMI DAERAH DALAM PERSEPEKTIF PEMBAGIAN URUSAN PEMERINTAH-PEMERINTAH DAERAH DAN KEUANGAN DAERAH
}

\author{
Fatkhul Muin \\ Fakultas Hukum Universitas Sultan Ageng Tirtayasa Serang dengan \\ konsentrasi Hukum Tata Negara
}

\begin{abstract}
Framework of the Unitary Republic of Indonesia of the concepts embodied in the provisions of Article 18 paragraph (1) of the Constitution of the Republic of Indonesia in 1945, the Republic of Indonesia is divided into provincial regions and districts are divided into, each province, district government gets, the regulated by law. Local authorities at provincial and district levels have different strengths according to the level. With patterns and delegation of authority given to the attributes of the local government is subject to the provisions of Law No. 32 of 2004 on local governments, to organize and manage themselves well with the pattern of decentralization of government policy. In carrying out regional autonomy, which is assisted by the head unit area of each region as part of the elements to run local autonomy. Financial management should be based on the concept of accountability and transparency to the public.
\end{abstract}

Keywords: Local Government and Affairs Division of the Central Government and Local Government

\section{abstrak}

Kerangka Negara Kesatuan Republik Indonesia dari konsep yang terkandung pada ketentuan pasal 18 ayat (1) Undang-Undang Dasar Republik Indonesia tahun 1945, Republik Indonesia dibagi menjadi daerah provinsi dan kabupaten dibagi ke dalam, yang masing-masing provinsi, pemerintah daerah kabupaten mendapat, yang diatur oleh undang-undang. Kewenangan pemerintah daerah di tingkat provinsi maupun kabupaten memiliki kekuatan yang berbeda sesuai dengan tingkat. Dengan pola dan delegasi atribut kewenangan yang diberikan kepada pemerintah daerah tunduk pada ketentuan di UU nomor 32 tahun 2004 tentang pemerintah daerah, untuk mengatur dan mengurus diri sendiri dengan baik dengan pola kebijakan desentralisasi pemerintahan. Dalam menjalankan otonomi daerah, yang dibantu oleh kepala satuan luas dari setiap daerah sebagai bagian dari elemen 
untuk menjalankan otonomi daerah. Manajemen keuangan harus didasarkan pada konsep akuntabilitas dan transparansi kepada publik .

Kata Kunci: Pemerintah Daerah dan Urusan Divisi dari Pemerintah Pusat dan Pemerintah Daerah

\section{A. Pendahuluan}

Konsep negara kesatuan tidak ada kedaulatan cabang, sehingga tidak konflik kewenangan antara pemerintah pusat dengan daerah, daerah selalu tunduk dan merupakan subordinat dari pemerintah pusat. Pendapat yang sama diungkapkan oleh Hans Antlov yang dikutip oleh Suharizal bahwa prinsip negara kesatuan berlandaskan kepada kedaulatan negara secara keseluruhan, lebih lanjut mengemukakan :

"the unitary principle ground sovereignity in the nation as a whole. A Goverment represing a unitry nation has right to delegate powers downward to region and local institutions, through legislation, but the region have no right to any og these powers. A Unitery staste can higly cantralized (like france) or it can be decentralized, with a substatial degree of autonomy of for provinces or communes (like Britain and Nethreland) At any rate, it is a unitry satate. The power held by local and region organs have been received from above, and can be withdrawn throught new legislation without any need for consent from the communes or provinces concerned".

Pendapat Hans Antlov tersebut mengandung pengertian bahwa dalam negara kesatuan baik yang sentralistik maupun desentralistik yang diberikan hak otonom ke daerah atau organ atau institusi merupakan pemberian pemerintah pusat, pemberian hak otonom itu dapat ditarik baik kewenangan maupun peraturan perundang-undangan tingkat daerah tanpa harus meminta persetujuan terlebih dahulu dari daerah. ${ }^{1}$ Sedangkan istilah otonomi berasal dari dua kata bahasa Yunani, yaitu autos (sendiri), dan nomos (peraturan) atau "undang-undang". Oleh karena itu, otonomi berarti peraturan sendiri atau undang-undang sendiri, yang selanjutnya berkembang menjadi pemerintahan sendiri. Dalam terminologi ilmu pemerintahan dan hukum administrasi negara, kata otonomi ini sering dihubungkan dengan kata otonomi daerah. Menurut Fernandez yang dikutip oleh Dharma Setyawan Salam, bahwa otonomi daerah adalah pemberian hak, wewenang, dan kewajiban kepada daerah memungkinkan daerah tersebut dapat mengatur dan mengurus rumah tangganya sendiri untuk meningkatkan daya guna dan

\footnotetext{
1. Suharizal, Demokrasi Pemilukada Dalam Sisitem Ketatanegaraan RI, (Bandung: UNPAD Press, 2012), hlm. 54-55.
} 
hasil guna penyelenggaraan pemerintahan dalam rangka pelayanan terhadap masyarakat dan pelaksanaan pembangunan. ${ }^{2}$

Ketentuan Pasal 1 angka 5 Undang-Undang No. 32 tahun 2004 Tentang Pemerintahan Daerah, Memberikan Deferensi bahwa Otonomi daerah adalah hak, wewenang, dan kewajiban daerah otonom untuk mengatur dan mengurus sendiri urusan pemerintahan dan kepentingan setempat sesuai dengan peraturan perundang-undangan. Suatu daerah, disebut sebagai daerah otonom apabila memiliki atribut sebagai berikut ${ }^{3}$ :

a. mempunyai urusan tertentu yang disebut urusan rumah tangga daerah; urusan rumah tangga daerah ini merupakan urusan yang diserahkan oleh pemerintah pusat kepada daerah;

b. urusan rumah tangga daerah itu diatur dan diurus/ diselenggarakan atas inisiatif/prakarsa dan kebijaksanaan daerah itu sendiri;

c. untuk mengatur dan mengurus rumah tangga daerah tersebut, maka daerah memerlukan aparatur sendiri yang terpisah dari aparatur pemerintah pusat, yang mampu untuk menyelenggarakan urusan rumah tangganya sendiri; dan

d. mempunyai sumber keuangan sendiri yang dapat menghasilkan pendapatan yang cukup bagi daerah, agar dapat membiayai segala kegiatan dalam rangka penyelenggaraan rumah tangga daerahnya.

Menurut Prof. Soepomo, bahwa otonomi daerah sebagai prinsip berarti menghormati kehidupan regional menurut riwayat, adat, dan sifat sendiri-sendiri, dalam kadar Negara Kesatuan. Tiap-tiap daerah mempunyai histori dan sifat khusus yang berlainan daripada riwayat dan sifat daerah lain. Berhubungan dengan itu, Pemerintah harus menjauhkan segala usaha yang bermaksud akan menguniformisir seluruh daerah menurut satu model. ${ }^{4}$ Menurut Smith yang melakukan kajian otonomi daerah, menyatakan bahwa perlu dipahami bahwa perluasan otonomi daerah tidak kecil kemungkinan juga dapat membuka peluang semakin terkonsentrasinya kekuasaan di antara local state-actors (birokrat dan politisi lokal). Ini adalah salah satu bahaya dari perluasan otonomi daerah yang perlu dicermati. Bila kecenderungan ini terjadi, maka masih terlalu dini untuk berharap bahwa kebijakan otonomi daerah akan dengan serta merta membuka peluang yang lebih luas kepada civil society untuk berpartisipasi dalam baik pada proses pengambilan

2. Dharma Setyawan Salam, Otonomi Daerah Dalam Persepektif Lingkungan, Nilai dan Sumber daya, (Jakarta: Djembatan), hlm. 88-89.

${ }^{3}$. Josep Riwu Kaho, Prospek Otonomi Daerah di Negara Republik Indonesia (Identifikasi beberapa faktor yang mempengaruhi penyelenggaraannya), (Jakarta: Raja Grafindo Persada, 2004), hlm. 80.

${ }^{4}$. Ibid.,hlm. 46. 
keputusan pada tingkat lokal, maupun pada tahap pelaksanaan dari berbagai keputusan tersebut. ${ }^{5}$

Menurut Smith yang dikutip oleh Dharma Setyawan Salam ${ }^{6}$, bahwa faktor yang dapat memprediksi keberhasilan otonomi daerah adalah fungsi dan tugas pemerintahan, kemampuan penguatan pajak daerah, bidang tugas administrasi, jumlah pelimpahan kewenangan, besarnya anggaran belanja, wilayah, ketergantungan keuangan, dan personil. Secara filosofi, penyelenggaraan otonomi daerah adalah bentuk pengakuan pemerintah pusat terhadap kemandirian masyarakat dan pemerintah kabupaten dan kota. Karena itu, sasaran akhir penyelenggaraan otonomi daerah adalah pemberdayaan masyarakat dan pemerintah daerah serta mendekatkan pelayanan pemerintah kepada masyarakat. ${ }^{7}$

Pelaksanaan otonomi daerah kelihatannya memang sederhana. Namun sebenarnya mengandung pengertian yang cukup rumit, karena di dalamnya tersimpul makna pendemokrasian dalam arti pendewasaan politik rakyat daerah, pemberdayaan masyarakat, dan sekaligus bermakna mensejahterakan rakyat berkeadilan. ${ }^{8}$ Reformasi di Indonesia yang terjadi pada tahun 1998 yang menghendaki adanya perubahan terhadap sistem pemerintahan di Indonesia dari pemerintahan pusat sampai pemerintah daerah dengan melakukan amandemen terhadap Undang-Undang Dasar Negara Republik Indonesia Tahun 1945 dan perubahan terhadap undang-undang, dimana salah satunya adalah Undang-Undang Pemerintahan Daerah. Perubahan undang-undang pemerintah daerah sebagai bagian dari semangat reformasi mengakibatkan perubahan pola hubungan pemerintah pusat dan pemerintah daerah, pola pengelolaan keuangan pemerintah daerah.

\section{B. Pembahasan}

\section{Pembagian Urusan Pemerintah-Pemerintah Daerah}

Kewenangan pemerintah merupakan dasar utama baik setiap tindakan dan perbuatan hukum dari setiap level pemerintahan, dengan adanya dasar kewenangan yang sah maka setiap tindakan dan perbuatan hukum yang dilakukan oleh setiap level pemerintahan dapat dikategorikan sebagai tindakan dan perbuatan hukum yang sah dan apabila tanpa ada dasar kewenangan, maka setiap tindakan dan perbuatan hukum yang dilakukan oleh setiap level pemerintah dapat dikategorikan sebagai tindakan dan perbuatan yang bertentangan dengan hukum dan dapat juga dikatakan

5. Syarif Hidayat, Refleksi Realitas Otonomi Daerah dan Tantangan Kedepan, (Jakarta: Pustaka Quantum, 2002), hlm. 33.

6. Op. Cit.....Dharma, hlm. 109.

7. Op. Cit..... Dharma, hlm. 75.

${ }^{8}$. Bambang Yudoyono, Otonomi Daerah (Desentralisasi dan Pengembangan SDM Aparatur Pemda dan Anggota DPRD), (Jakarta: Pustaka Sinar Harapan, 1999), hlm. 7. 
sebagai pelanggaran terhadap asas-asas umum pemerintahan yang baik. Secara umum, kewenangan pemerintahan dapat diperoleh melalui atribusi, delegasi, dan mandat serta tugas pembantuan (medebewind). Cara memperoleh kewenangan tersebut juga menggambarkan adanya perbedaan yang hakiki antara berbagai level pemerintahan yang ada di suatu negara. Sebagai contoh, pelaksanaan atribusi kewenangan memerlukan adanya pembagian level pemerintahan yang bersifat nasional, regional, dan lokal atau level pemerintahan atasan dan pemerintahan bawahan. Selain itu pelaksanaan delegasi membuktikan adanya level pemerintahan yang lebih tinggi (delegator) dan level pemerintahan yang lebih rendah (delegans). Secara khusus, kewenangan pemerintahan juga berkaitan dengan hak, kewajiban, dan tanggung jawab di antara berbagai level pemerintahan yang ada. Dengan adanya pembagian atribusi, distribusi, delegasi, dan mandat dapat digambarkan bagaimana berbagai level pemerintahan tersebut mempunyai hak, kewajiban, dan tanggung jawab yang berbeda antara satu level pemerintahan dengan level pemerintahan lainnya. Dengan demikian, terjadi perbedaan tugas dan wewenang di antara berbagai level pemerintahan tersebut, dan pada akhirnya dapat menciptakan perbedaan ruang lingkup kekuasaan dan tanggung jawab di antara mereka. ${ }^{9}$

Sesuai dengan amanat Undang-Undang Nomor 23 Tahun 2014 tentang Pemerintahan Daerah, pemerintahan daerah menyelenggarakan urusan pemerintahan yang menjadi kewenangannya, kecuali urusan pemerintahan yang menjadi urusan Pemerintah. Dalam menyelenggarakan urusan pemerintahan yang menjadi kewenangan daerah tersebut, pemerintahan daerah menjalankan otonomi seluas-luasnya untuk mengatur dan mengurus sendiri urusan pemerintahan berdasarkan asas otonomi dan tugas pembantuan. Penyelenggaraan desentralisasi mensyaratkan pembagian urusan pemerintahan antara Pemerintah dengan Pemerintahan Daerah. Urusan pemerintahan terdiri dari urusan pemerintahan yang sepenuhnya menjadi kewenangan Pemerintah dan urusan pemerintahan yang dikelola secara bersama antar tingkatan dan susunan pemerintahan atau konkuren. Urusan pemerintahan yang sepenuhnya menjadi kewenangan pemerintah adalah urusan dalam bidang politik luar negeri, pertahanan, keamanan, moneter dan fiskal nasional, yustisi, dan agama. Urusan pemerintahan yang dapat dikelola secara bersama antar tingkatan dan susunan pemerintahan atau konkuren adalah urusan-urusan pemerintahan selain urusan pemerintahan yang sepenuhnya menjadi urusan Pemerintah. Dengan demikian dalam setiap bidang urusan pemerintahan yang bersifat konkuren senantiasa terdapat bagian urusan yang menjadi kewenangan Pemerintah,

\footnotetext{
${ }^{9}$.http://www.akilmochtar.com/wp-content/uploads/2011/06/Kewenangan-Pusat-Dan-DaerahDalam-Pembangunan-Daerah-Di-Era-Otonomi..pdf diunduh pada tanggal 10 Januari 2013, jam 15.00.
} 
Pemerintahan Daerah Provinsi, dan Pemerintahan Daerah Kabupaten/Kota. Untuk mewujudkan pembagian urusan pemerintahan yang bersifat konkuren tersebut secara proporsional antara Pemerintah, Pemerintahan Daerah Provinsi, dan Pemerintahan Daerah Kabupaten/Kota maka ditetapkan kriteria pembagian urusan pemerintahan yang meliputi eksternalitas, akuntabilitas, dan efisiensi. Penggunaan ketiga kriteria tersebut diterapkan secara kumulatif sebagai satu kesatuan dengan mempertimbangkan keserasian dan keadilan hubungan antar tingkatan dan susunan pemerintahan. $^{10}$

Pembagian urusan antara pemerintah, pemerintah provinsi dan pemerintah kabupaten/kota sebagai upaya untuk memperjelas kewenangan masing-masing pemerintah dalam menjalankan kewenangannya dan mengurus rumah tangganya sendiri. Secara umum, berdasarkan pasal 6 Ayat (1 dan 2) Peraturan Pemerintah No. 38 Tahun 2007 tentang Pembagian Urusan Pemerintahan antara Pemerintah, Pemerintah Provinsi, Pemerintah Kabupaten/Kota, pemerintah yang menjadi kewenangan pemerintah daerah teridiri dari urusan wajib dan urusan pilihan. Urusan wajib terdiri dari :

a) pendidikan;

b) kesehatan;

c) lingkungan hidup;

d) pekerjaan umum;

e) penataan ruang;

f) perencanaan pembangunan;

g) perumahan;

h) kepemudaan dan olahraga;

i) penanaman modal;

j) koperasi dan usaha kecil dan menengah;

k) kependudukan dan catatan sipil;

1) ketenagakerjaan;

m) ketahanan pangan;

n) pemberdayaan perempuan dan perlindungan anak;

o) keluarga berencana dan keluarga sejahtera;

p) perhubungan;

q) komunikasi dan informatika;

r) pertanahan;

s) kesatuan bangsa dan politik dalam negeri;

t) otonomi daerah, pemerintahan umum, administrasi keuangan daerah, perangkat daerah, kepegawaian, dan persandian;

u) pemberdayaan masyarakat dan desa;

\footnotetext{
${ }^{10}$. Lihat Penjelasan PP No. 38 Tahun 2007 Tentang Pembagian Urusan Pemerintahan antara Pemerintah, Pemerintah Provinsi, Pemerintah Kabupaten/Kota.
} 
v) sosial;

w) kebudayaan;

x) statistik;

y) kearsipan; dan

z) perpustakaan.

Sedangkan urusan pilihan adalah urusan pemerintahan yang secara nyata ada dan berpotensi untuk meningkatkan kesejahteraan masyarakat sesuai dengan kondisi, kekhasan, dan potensi unggulan daerah yang bersangkutan. ${ }^{11}$ Pembagian urusan dalam kewenangan antara pemerintah dan pemerintah daerah pada tingkat Provinsi, Kabupaten, dan Kota merupakan batasan dalam pelaksanaan otonomi daerah yang riil dan nyata, sehingga tidak adanya pengambilan urusan yang bukan dari kewenangannya dan tidak mengakibatkan konflik vertikal antara lembaga-lembaga yang ada, karena ada batasan-batasan urusan yang menjadi kewenangan.

\section{Keuangan Daerah}

Anggaran Pendapatan dan Belanja Negara (APBN) merupakan alat utama pemerintah untuk menyejahterakan rakyatnya dan sekaligus alat pemerintah untuk mengelola perekonomian negara. Sebagai alat pemerintah, APBN bukan hanya menyangkut keputusan ekonomi, namun juga menyangkut keputusan politik. Dalam konteks ini, DPR dengan hak legislasi, penganggaran, dan pengawasan yang dimilikinya perlu lebih berperan dalam mengawal APBN sehingga APBN benar-benar dapat secara efektif menjadi instrumen untuk menyejahterakan rakyat dan mengelola perekonomian negara dengan baik. Dalam rangka mewujudkan good governance dalam penyelenggaraan pemerintahan negara, sejak beberapa tahun yang lalu telah dilakukan Reformasi Manajemen Keuangan Pemerintah. Reformasi tersebut mendapatkan landasan hukum yang kuat dengan telah disahkannya Undang-undang Nomor 17 Tahun 2003 tentang Keuangan Negara, Undang-undang Nomor 1 Tahun 2004 tentang Perbendaharaan Negara, dan Undang-undang Nomor 15 Tahun 2004 tentang Pemeriksaan Pengelolaan dan Tanggung jawab Keuangan Negara. ${ }^{12}$

Secara umum berdasarkan Undang-undang No. 17 Tahun 2003 Tentang Keuangan Negara, ada beberapa prinsip-prinsip pengelolaan keuangan negara meliputi:

11. Pembagian urusan wajib dan urusan pilihan yang terdapat dalam ketentuan PP No. 38 Tahun 2007, secara konkret membagi urusan kewenangan pemerintah, pemerintah daerah provinsi, kabupaten/kota, sehingga dalam kebijakan yang diambil oleh masing-masing tingkatan pemerintah tidak adanya konflik vertikal da horizontal.

12. Keuangan Negara (Modul Latihan Kepemimpinan III), (Lembaga Administrasi Negara, 2001), hlm. 11. 
1) tertib, artinya bahwa pengelolaan keuangan negara harus selalu memperhatikan tertib administrasi dan tertib secara operasional;

2) taat pada peraturan perundang-undangan, artinya bahwa pengelolaan keuangan negara harus selalu sesuai dengan peraturan perundangundangan yang berlaku;

3) efisien, artinya bahwa pengelolaan keuangan negara harus efisien dan tidak boros;

4) ekonomis, artinya bahwa dalam pengelolaan keuangan negara harus memperhatikan keterbatasan keuangan yang ada dengan pengalokasian sesuai dengan prioritas;

5) efektif, artinya bahwa pengelolaan keuangan negara harus berorientasi kepada pencapaian tujuan pembangunan;

6) transparan, artinya bahwa pengelolaan keuangan negara harus terbuka sesuai dengan peraturan perundang-undangan yang berlaku;

7) bertanggungjawab, artinya bahwa setiap rupiah uang negara yang dikeluarkan harus dapat dipertanggungjawabkan kepada publik sesuai dengan peraturan perundangan yang berlaku; dan

8) memperhatikan rasa keadilan dan kepatutan, artinya bahwa dalam pengelolaan keuangan negara harus selalu memperhatikan keadilan di antara warga negara, daerah, dan sektor, serta sesuai dengan norma dan kepatutan yang berlaku di masyarakat.

Sedangkan dalam penyusunan Anggaran Pendapatan dan Belanja Daerah merupakan bagian dari sistem keuangan negara yang diatur dalam Undang-Undang Nomor 17 Tahun 2003. Demikian pula, penyusunan APBD merupakan bagian tak terpisahkan dari sistem pengelolaan Pemerintah Daerah sebagaimana diatur dalam Undang-Undang Nomor 32 Tahun 2004. Salah satu sumber pendanaan pembangunan daerah bersumber dari APBN, sehingga proses penyusunan APBD juga diatur dalam Undang-Undang Nomor 33 Tahun 2004 tentang Perimbangan Keuangan antara Pemerintah Pusat dan Daerah. Proses penganggaran diatur dalam Peraturan Pemerintah Nomor 58 Tahun 2005 tentang Pengelolaan Keuangan Daerah. Dalam pelaksanaan Pengelolaan Keuangan Daerah Menteri Dalam Negeri menetapkan Peraturan Menteri Dalam Negeri Nomor 13 Tahun 2006 tentang Pedoman Pengelolaan Keuangan Daerah, sebagaimana telah diubah dengan Peraturan Menteri Dalam Negeri Nomor 21 Tahun 2011 tentang Perubahan kedua atas Permendagri No. 13 tahun 2006 tentang Pedoman Pengeloaan Keuangan Daerah. ${ }^{13}$

APBD (Anggaran Pendapatan dan Belanja Daerah) merupakan dasar pengelolaan keuangan daerah dalam masa 1 (satu) tahun anggaran

\footnotetext{
${ }^{13}$.http://www.diklatbanyumas.net/kti/goto/siklus_anggaran.pdf, diunduh pada [ 15 Januari 201], jam 15.00.
} 
terhitung mulai 1 Januari sampai dengan tanggal 31 Desember. Kepala daerah dalam penyusunan rancangan APBD menetapkan prioritas dan plafon anggaran sebagai dasar penyusunan rencana kerja dan anggaran satuan kerja perangkat daerah. Berdasarkan Prioritas dan plafon anggaran kepala satuan kerja perangkat daerah menyusun rencana kerja dan anggaran satuan kerja perangkat daerah dengan pendekatan berdasarkan prestasi kerja yang akan dicapai. Rencana kerja dan anggaran satuan kerja perangkat daerah disampaikan kepada pejabat pengelola keuangan daerah sebagai bahan penyusunan rancangan Perda tentang APBD tahun berikutnya. Kepala daerah mengajukan rancangan Perda tentang APBD disertai penjelasan dan dokumen-dokumen pendukungnya kepada DPRD untuk memperoleh persetujuan bersama. ${ }^{14}$

Menurut pasal 194 UU No. 32 tahun 2004 Tentang Pemerintahan Daerah, bahwa Penyusunan, pelaksanaan, penatausahaan, pelaporan, pengawasan, dan pertanggungjawaban keuangan daerah diatur lebih lanjut dengan Perda yang berpedoman pada Peraturan Pemerintah. Dengan ketentuan tersebut, menjadi dasar hukum bagi proses pengelolaan keuangan daerah dan untuk menciptakan akuntabilitas dan transparansi keuangan negara.

\section{Penutup}

Konsep negara kesatuan tidak ada kedaulatan cabang, sehingga tidak konflik kewenangan antara pemerintah pusat dengan daerah, daerah selalu tunduk dan merupakan subordinat dari pemerintah pusat. Dalam menjalankan otonomi daerah, pemerintah daerah memiliki kewenangan dimana kewenangan tersebut berkaitan dengan hak, kewajiban, dan tanggungjawab di antara berbagai level pemerintahan yang ada. Dengan adanya pembagian atribusi, distribusi, delegasi, dan mandat dapat digambarkan bagaimana berbagai level pemerintahan tersebut mempunyai hak, kewajiban, dan tanggungjawab yang berbeda antara satu level pemerintahan dengan level pemerintahan lainnya. Dalam ketentuan PP 38 Tahun 2007, tentang Pembagian Urusan Pemerintah, Pemerintah Daerah Provinsi, dan Pemerintah Daerah kabupaten/Kota, dimana secara umum ada 2 (dua) urusan, yaitu urusan wajib dan urusan pilihan. Selaian itu dalam menjalankan pemerintahannya, dimana penyusunan Anggaran Pendapatan dan Belanja Daerah merupakan bagian dari sistem keuangan negara yang diatur dalam Undang-Undang Nomor 17 Tahun 2003. Demikian pula, penyusunan APBD merupakan bagian tak terpisahkan dari sistem pengelolaan Pemerintah Daerah sebagaimana diatur dalam Undang-Undang Nomor 32 Tahun 2004. Salah satu sumber pendanaan pembangunan daerah

${ }^{14}$. Lihat pasal 179, 180, 181 dan 182 UU No. 32 tahun 2004 Tentang Pemerintahan Daerah. 
bersumber dari APBN, sehingga proses penyusunan APBD juga diatur dalam Undang-Undang Nomor 33 Tahun 2004 tentang Perimbangan Keuangan antara Pemerintah Pusat dan Daerah. Proses penganggaran diatur dalam Peraturan Pemerintah Nomor 58 Tahun 2005 tentang Pengelolaan Keuangan Daerah. Dalam pelaksanaan Pengelolaan Keuangan Daerah Menteri Dalam Negeri menetapkan Peraturan Menteri Dalam Negeri Nomor 13 Tahun 2006 tentang Pedoman Pengelolaan Keuangan Daerah, sebagaimana telah diubah dengan Peraturan Menteri Dalam Negeri Nomor 21 Tahun 2011 tentang Perubahan kedua atas Permendagri No. 13 tahun 2006 tentang Pedoman Pengeloaan Keuangan Daerah.

\section{Daftar Pustaka}

\section{A. Buku}

Hidayat, Syarif, 2001. Refleksi Realitas Otonomi Daerah dan Tantangan Kedepan, Jakarta: Pustaka Quantum.

Kaho, Josef Riwu, Prospek Otonomi Daerah di Negara Republik Indonesia (Identifikasi beberapa faktor yang mempengaruhi penyelenggaraannya), Jakarta: Raja Grafindo Persada.

Keuangan Negara (Modul Latihan Kepemimpinan III), 2001. Lembaga Administrasi Negara.

Salam, Dharma Setyawan, Otonomi Daerah Dalam Persepektif Lingkungan, Nilai dan Sumber daya, Jakarta: Djembatan.

Suharizal, 2012. Demokrasi Pemilukada Dalam Sisitem Ketatanegaraan RI, Bandung: UNPAD Press.

Yudoyono, Bambang, 2000. Otonomi Daerah (Desentralisasi dan Pengembangan SDM Aparatur Pemda dan Anggota DPRD), Jakarta: Pustaka Sinar Harapan.

\section{B. Undang-Undang}

Undang-Undang Dasar Negara Republik Indonesia Tahun 1945.

Undang-Undang No. 17 Tahun 2003 Tentang Keuangan Negara.

Undang-Undang No. 32 Tahun 2004 Tentang Pemerintahan Daerah.

Undang-Undang No. 33 Tahun 2004 tentang Perimbangan Keuangan antara Pemerintah Pusat dan Daerah.

PP No. 58 Tahun 2005 tentang Pengelolaan Keuangan Daerah.

PP No. 38 Tahun 2007 Tentang Pembagian Urusan Pemerintah, Pemerintah

Daerah Provinsi, Pemerintah Daerah Kabupaten/Kota. 


\section{Website}

http://www.akilmochtar.com/ 